\title{
МЕХАНИЗМЫ ФОРМИРОВАНИЯ СОЦИАЛЬНОЙ БАЗЫ БОЛЬШЕВИЗМА В СТЕПНОМ КРАЕ В ПЕРИОД ГРАЖДАНСКОЙ ВОЙНЫ (1918-1921 ГГ.)

\author{
Ю.А. Лысенко
} \\ Алтайский государственньій университет, Барнаул, Россия, e-mail: iulia_199674@mail.ru
}

Анализируется социально-политическая ситуация в Степном крае в период Гражданской войны 1918-1922 гг. В эти годы в регионе происходило мощное идеологическое противостояние большевиков с их политическими оппонентами в борьбе за власть. Стремление большевиков к ее монопольному захвату и формированию однопартийной системы осложнялась отсутствием у них социальной базы и наличием мощной оппозиции в лице этнополитических организаций. Укрепление политического влияния РКП(б) в Степном крае в период Гражданской войны осуществлялось посредством конструирования советских органов власти и регионального отделения РКП(б) с использованием арсенала идеологических и социально-экономических средств.

Ключевые слова: Гражданская война, Степной край, большевики, Алаш, советизация, власть, однопартийная система, ислам.

\section{MECHANISMS OF FORMATION OF SOCIAL BASE OF BOLSHEVISM IN THE STEPPE REGION DURING THE CIVIL WAR (1918-1921)}

\author{
Yu.A. Lysenko \\ Altai State University, Barnaul, Russia, \\ e-mail: : iulia_199674@mail.ru
}

The article analyzes the socio-political situation in the Steppe region during the civil war of 1918-1922. During these years, the region experienced a powerful ideological confrontation between the Bolsheviks and their political opponents in the struggle for power. The Bolsheviks ' desire for its monopolistic seizure and the formation of a one-party system was complicated by their lack of a social base and the presence of a powerful opposition in the face of ethno-political organizations.

\footnotetext{
${ }^{1}$ Исследование выполнено за счет гранта Российского научного фонда (проект №19-18-00180)
} 
Strengthening the political influence of the $\mathrm{RCP}(\mathrm{b})$ in the Steppe region during the civil war was carried out through the construction of the Soviet authorities and the regional branch of the $\mathrm{RCP}(\mathrm{b})$ using an Arsenal of ideological and socio-economic means.

Keywords: Civil war, Steppe region, Bolsheviks, Alash, Sovietization, power, one-party system, Islam.

DOI 10.14258/ssi(2019)3-6436

\section{Введение}

По оценкам современной историографии в период Гражданской войны в России 1918-1921 гг. произошла существенная трансформация политической системы, связанная с фактическим захватом власти большевиками и формированием однопартийной системы. Поэтому, как считает ряд исследователей, термин «советская власть» «не может претендовать на адекватное отражение той структуры политической организации, которая установилась в России в период гражданской войны» (Булдаков, Кабанов, 1990; Булдаков, 1997; Павлюченков, 1997).

\section{Основные результаты}

В полной мере данный тезис экстраполируется и на Центрально-Азиатский регион России. В Степном крае реализация большевиками своей политической программы еще накануне Гражданской войны встретила ряд объективных препятствий. Во-первых, невысокие темпы промышленного развития региона в начале XX в. обусловили отсутствие социальной базы большевизма - численность местного пролетариата накануне 1917 г. составляла 50 тыс. человек (Покровский, 1967: 92). Во-вторых, аграрная политика имперского периода в Степном крае, исключавшая формирование крупного частного землевладения и направленная на землеустройство крестьян-переселенцев и местного казачества, делала слабо восприимчивым русское аграрное население региона к эсеро-большевистским лозунгам «социализации земли». Нерешенная проблема землеустройства казахов-скотоводов не рассматривалась большевиками как ресурс влияния, по крайней мере, до октября 1917 г. В-третьих, серьезную политическую конкуренцию в Степном крае большевикам в послеоктябрьский период составила партия казахской интеллигенции Алаш. Популярность партии привела ее к победе на выборах во Всероссийское Учредительное собрание, состоявшихся в январе 1918 г. По итогам II Общеказахского съезда (5-13 декабря 1917 г.) лидеры партии приступили к созданию национально-территориальной автономии Алаш с широкими политическими полномочиями (Движение Алаш..., 2005: 130).

Данные факторы предопределили противоречивость «триумфального шествия» советской власти в Степном крае, затянувшегося до весны 1918 г. Наиболее безболезненно создание Советов прошло в районах концентрации железнодорожных рабочих по линии Туркестанско-Оренбургской железной дороги. В более сложной обстановке она утверждалась в Уральской и Тургайской областях, на се- 
веро-востоке Степного края и в Семиречье, что объяснялось наличием здесь оппозиционных большевикам сил - Уральского, Оренбургского и Семиреченского казачьих войск. Весной 1918 г. большевики приступили к созданию альтернативной Алаш-Орде автономии на советских началах. Однако работа партийных органов по закреплению своих политических позиций в Степном крае, созданию краевой партийной организации РКП(б) и Казахской автономии была прервана начавшейся Гражданской войной.

Вернуться к реализации намеченных планов большевики смогли в начале 1919 г. после серии крупных побед Красной армии и освобождения большей территории региона от белогвардейцев. К этому моменту актуальной продолжала оставаться проблема отсутствия социальной базы большевизма и широкой сети партийных организаций РКП(б) в Степом крае. Поэтому в освобожденных от белогвардейцев районах большевики развернули мощную политико-пропагандистскую работу, которой были охвачены фактически все этносоциальные группы. Особое внимание уделялось работе среди казахов. Главный лозунг, на который была сделана ставка, - это тяжелое колониальное наследие региона, связанное с проводившимися земельными экспроприациями у казахов в пользу крестьян-переселенцев (Григорьев, 1984: 176). В сознание скотоводов активно внедрялась мысль о скорейшем разрешении «аграрного вопроса» и возвращении «казахскому трудовому народу отнятой у него царизмом земли». В качестве примера приводилось постановление IX Всетуркестанского съезда Советов (сентябрь 1920 г.), узаконившее возвращение коренному населению всех земель, переданных русским крестьянам, и нашедшее практическую реализацию в высылке в 1921 г. 18970 русских из Семиреченской области, ликвидации 49 поселков, 95 хуторов (Генис, 1998: 45).

Мощным агитационным средством большевиков стало введение делопроизводства на казахском языке и повсеместно вводившаяся практика коренизации административного аппарата (Иностранная военная..,, 1964: 662-663). Огромное значение в закреплении позиций большевиков в Степном крае сыграл факт перехода части казахской интеллигенции и участников алашского движения на сторону советской власти, в чем были заинтересованы как большевики, так и лидеры казахского национального движения.

Коммунистической пропагандой было охвачено и русское аграрное население Степного края. Определяющим тактическим решением политики большевиков в отношении уральского, сибирского и семиреченского казачества, а также крестьян-переселенцев стала ставка на их социальную неоднородность, разжигание социальных противоречий и привлечение на свою сторону беднейших и середняцких слоев. Повсеместно создаваемые в Степном крае комитеты бедноты оказывали помощь государственным органам в проведении продовольственных реквизиций, осуществлявшихся в отношении зажиточных крестьянских хозяйств. Огромное политико-пропагандистское значение имел декрет СНК РСФСР «Об оказании помощи населению Уральской области» от 7 декабря 1919 г., принятый после разгрома Красной армией Уральского казачьего войска. В декрете уральскому белоказачеству гарантировалась безопасность и «забвение всех прежних вин» при условии при- 
знания Советской власти. 2 марта 1920 г. последовало аналогичное постановление за подписью командующего Туркестанским фронтом М.В. Фрунзе в отношении семиреченского казачества (Покровский, 1967: 320).

Непосредственная работа большевиков по укреплению политической власти в Степном крае при отсутствии краевого отделения РКП(б) и системы Советов осуществлялась под руководством Казахского революционного комитета (Казревкома) и местных революционных комитетов - ревкомов. Казревком был сформирован 10 июля 1919 г. декретом СНК РСФСР. Его персональный состав формировался в новой для большевиков политической ситуации, когда уже был достигнут известный компромисс между ними и лидерами Алашского движения и произошел переход некоторой части казахской интеллигенции на сторону Советов. В первый и последующий составы Казревкома наряду с активными советскими/коммунистическими работниками (А. Жангельдин, Б. Каратаев, С. Мендешев и др.) были включены видные деятели Алашского движения и противники большевиков (А. Байтурсынов, Б. Каралдин, А. Алибеков и др.) (Аманжолова, 1994).

Казревком сосредоточил в своих руках высшее военно-гражданское управление краем и руководил им фактически до созыва Всеказахского съезда Советов и образования КазАССР - 10 октября 1920 г. Функционирование Казревкома происходило в условиях жесткой борьбы между его членами - коммунистами, проводившими линию Центра, с одной стороны, и бывшими алашордынцами - с другой. Наиболее остро противостояние проявилось в ходе определения границ будущей Казахской автономии и подготовке проекта конституционных принципов ее государственного устройства. В их основу был заложен классовый подход, что вызывало сопротивление со стороны членов Казревкома - бывших алашевцев (Елагин, 1996: 295-296; Зиманов, 1981: 183).

Учредительный съезд КазАССР проходил с 1 по 12 октября 1920 г. Важнейшим политическим документом, принятым на съезде, стала Декларация прав трудящихся Киргизской (Казахской) АССР. Она определила основные принципы образования автономии, ее руководящие органы, основы организации и деятельности. Образование КазАССР являлось значительным событием в общественно-политической жизни центральноазиатских окраин России. В результате этого, хоть и в форме Советов, на основе классового принципа, была восстановлена государственность казахов с передачей им исконных земель. Это событие окончательно делало неизбежной победу большевиков в Гражданской войне.

Мощным рычагом идеологического воздействия на население Казахского края стала реализация большевистского проекта по созданию региональных революционных комитетов (ревкомов) (ЦГА РК. Ф. Р-1409. Оп. 1. Д. 15. Л. 5.). Наиболее активно в регионе они формировались весной — осенью 1919 г. Их образование мотивировалось слабостью или отсутствием Советов, «проникновением в них враждебных элементов», «сложностью противостояния многочисленным внутренним и внешним врагам». Поэтому ревкомы в политической риторике большевиков провозглашались как временные чрезвычайные органы диктатуры пролетариата. Их состав не избирался населением, а формировался путем назначения вышесто- 
ящими партийно-советскими органами и военным командованием Туркестанского фронта наиболее преданных советской власти коммунистов, имевших опыт административной и партийно-политической работы. Политическим оппонентам большевиков - адмнистированным лидерам западного отделения Алаш-Орды решением Казревкома было отказано в возможности участия в формировании советских органов власти (Протоколы революционного..., 1991: 65-66). В состав волостных и сельских ревкомов Степного края «назначались кандидаты из беднейшего класса населения, отдавалось ... преимущество людям, более или менее разбирающимся в политике и сочувствующим РКП(б)». Такая ситуация способствовала поляризации сельских обществ и разжиганию социального противостояния. Искусственно созданные ревкомы не были способны к нормальному функционированию и выполнению возложенных на них задач. Ситуацию усугублял тот факт, что вся работа ревкомов проводилась под непосредственным контролем местных партийных организаций, руководители губернских, областных и уездных комитетов партии входили непосредственно в состав ревкомов (ЦГА РК. Ф. Р-1409. Оп. 1. Д. 8. Л. 5-6). Таким образом, были заложены основы практики, которая закрепилась в последующие десятилетия развития СССР как партократического государства: двойного контроля со стороны партии за всеми административными народно-хозяйственными, экономическими субъектами.

Параллельно с укреплением политического влияния через работу Казревкома и местных ревкомов большевики вплотную подошли к формированию краевой партийной организации РКП(б). 11 апреля 1920 г. ЦК РКП(б) принял решение о создании Казахского областного бюро РКП(б), первоочередной задачей которого должно было стать формирование разветвленной сети партийных организаций в Казахском крае, их объединение в единую областную организацию РКП(б) и проведение организационной работы по подготовке и проведению первой краевой партийной конференции с целью создания единого краевого партийного центра (Очерки истории..., 1963: 173).

Казоблбюро РКП(б) в период 1920-1921 гг. удалось успешно преодолеть все организационные трудности и решить проблемы нехватки профессиональных большевиков-управленцев, отсутствия системы партячеек в Казахском крае. За эти два года партийные фракции РКП(б) были созданы фактически во всех административно-государственных органах, Советах, профсоюзах, кооперативах Казахского края. Важным механизмом партийного строительства большевиков в Казахском крае стало внедрение в общественно-политическую жизнь региона практик проведения партийных конференций, коммунистических субботников, «недель коммуниста», «недель крестьянина», беспартийных крестьянских конференций, мобилизаций коммунистов в Красную Армию (Очерки истории.., 1963: 174-185). Все данные мероприятия оказывали огромное политико-идеологическое воздействие на население края. После провозглашения КазАССР в октябре 1920 г. Казоблбюро получило основание для созыва I областной партийной конференции, которая состоялась в июне 1921 г. в Оренбурге. Итогом работы конференции стало создание Казахского областного комитета ЦК РКП(б). 


\section{Выводы}

В целом отметим, что укрепление политического влияния РКП(б) в Степном крае в период Гражданской войны 1918-1921 гг. было связано с демонтажом советских органов власти, созданием альтернативных им временных органов исполнительной власти - революционных комитетов, которым передавались огромные полномочия и состав которых формировался региональными органами РКП(б). Ревкомам и местным партийным организациям удалось преодолеть отчужденность русского аграрного населения Степного края, привлечь на свою сторону лидеров алаш-ордынского движения и рядовых казахов-скотоводов. Для этого использовался широкий арсенал методов и средств: пропагандистско-агитационная работа разновекторной направленности, коренизация аппарата управления, серия реформ по устранению «колониального наследия» региона. Кульминацией деятельности партийных органов Степном крае - Казревкома и местных ревкомов стало создание Казахской автономии на советских социалистических началах в 1920 г. и республиканской партийной организации в июне 1921 г. Присутствие в составе ЦИК, СНК КазАССР значительного числа членов Казахского областного комитета РКП(б) (А.Д. Авдеев, А.М. Асылбеков, А.Т. Жангельдин, С.М. Мендышев, В.А. Радус-Зенькович) позволяет сделать вывод о том, что республиканская партийная организация смогла стать единоличным органом высшей государственной власти в КазАССР.

\section{БИБЛИОГРАФИЧЕСКИЙ СПИСОК}

Аманжолова Д. Казахский автономизм и Россия. История движения Алаш. М., 1994. 213 c.

Булдаков В.П., Кабанов В.В. «Военный коммунизм»: идеология и общественное развитие. Вопросы истории, 1990, No. 3, 40-58.

Булдаков В.П. Красная смута. Природа и последствия революционного насилия. М., $1997.376 \mathrm{c}$.

Генис В.Л. Депортация русских из Туркестана в 1921 году («Дело Сафарова»). Вопросы истории, 1998, No. 1, 44-58.

Григорьев В.К. Разгром мелкобуржуазной контрреволюции в Казахстане. 1920 1922. Алма-Ата, 1984. 176 с.

Движение Алаш: сборник документов и материалов. Декабрь 1917 г. — май 1920 г. Алматы, 2005. Т. 2. 496 с.

Елагин А.С. Социалистическое строительство в Казахстане в годы Гражданской войны (1918-1920 гг.). Алма-Ата, 1966. 187 с.

Зиманов С.3. и др. Казахский Революционный Комитет. Алма-Ата, 1981. 193 с.

Иностранная военная интервенция и Гражданская война в Средней Азии и Казахстане: документы и материалы. Алма-Ата, 1964. Т. II. 673 с.

Кабанов В.В. Крестьянское хозяйство в условиях «военного коммунизма». М., 1988. $305 \mathrm{c}$. 
Очерки истории Коммунистической партии Казахстана. Алма-Ата, 1963. 672 с.

Павлюченков С.А. Военный коммунизм в России: власть и массы. М., 1997. 270 с.

Покровский С.Н. Разгром иностранных военных интервентов и внутренней контрреволюции в Казахстане (1918-1920 гг.). Алма-Ата, 1967. 365 с.

Протоколы Революционного комитета по управлению Казахским краем. 1919-1920: сборник документов. Алма-Ата, 1993. 277 с.

Центральный государственный архив Республики Казахстан (ЦГА РК).

\section{REFERENCES}

Amanzholova, D. (1994). Kazahskii avtonomizm i Rossia. Istoria dvizheniya Alash [Kazakh autonomism and Russia. History of the Alash movement]. M., 213 p.

Buldakov, V.P., Kabanov, V.V. (1990). «Voenniy kommunizm»: ideologia i obscshestvennoe razvitie [«War communism»: ideology and social development]. Voprosy istorii [Questions of history], no 3, 40-58.

Buldakov, V.P. (1997). Krasnaya smuta. Priroda I posledstviya revolucionnogo nasiliya [The nature and consequences of revolutionary violence]. M., $376 \mathrm{p}$.

Genis, V.L. (1998). Deportaciya russkih iz Turkestana v 1921 godu («Delo Safarova») [Deportation of Russians from Turkestan in 1921 («Safarov Case»)] Voprosy istorii [Questions of history], no 1, 44-58.

Grigoriev, V.K. (1984). Razgrom melkoburzhuaznoy kontrrevolucii v Kazahstane. 19201922 [The defeat of the petty-bourgeois counter-revolution in Kazakhstan. 1920-1922]. Alma-Ata, $176 \mathrm{p}$.

Dvizhenie Alash: sbornik dokumentov i materialov. Dekabr'1917 g. - maj 1920 g. [Alash Movement: collection of documents and materials. December 1917 — May 1920]. Almaty, 2005. Vol. 2. 496 p.

Elagin, A.S. (1966). Socialisticheskoe stroitelstvo v Kazahstane v gody Grazhdanskoy voiny (1918-1920) [Socialist construction in Kazakhstan during the Civil war (19181920)]. Alma-Ata, 187 p.

Zimanov, S.Z. et al. (1981). Kazahskii revolucionniy komitet. [Kazakh Revolutionary Committee]. Alma-Ata, 193 p.

Inostrannaya voennaya intervenciya i Grazhganskaya voina v Sredney Azii i Kazahstane: documenty and materialy [Foreign military intervention and Civil war in Central Asia and Kazakhstan: Documents and materials]. Alma-Ata, 1964. Vol 2. 673 p.

Kabanov, V.V. (1988). Krestyanskoe hozyaistvo v usloviyah "voennogo kommunizma» [Peasant economy in the conditions of "war communism"]. M., 305 p.

Ocherki istorii Kommunisticheskoy partii Kazahstana [Essays on the history of the Communist party of Kazakhstan]. Alma-Ata, 1963. 672 p.

Pavluchenkov, S.A. (1997). Voennii kommunizm v Rossii: vlast i massy [War communism in Russia: power and masses]. M., 270 p. 
Pokrovskii, S.N. (1967). Razgrom inostrannyh voennyh interventov i vnutrennei kontrrevolyucii v Kazahstane (1918-1920) [Defeat of foreign military interventionists and internal counter-revolution in Kazakhstan (1918-1920)]. Alma-Ata, 365 p.

Protokoly Revolyucionnogo komiteta po upravlniyu Kazahskim kraem. 1919-1920: sbornik dokumentov [Minutes of the Revolutionary Committee for the management of the Kazakh region. 1919-1920: Collection of documents]. Alma-Ata, 1993. 277 p.

Centralnii gosudarstvennii arhiv Respubliki Kazahstan (CGA RK) [Central state archive of the Republic of Kazakhstan] (CSA RK). 